\title{
Determination of virulence factors and antimicrobial resistance of $E$. coli isolated from calf diarrhea, part of eastern Turkey
}

\author{
Seyda CENGíZ ${ }^{1, a,}$, Mehmet Cemal ADIGÜZEL ${ }^{1, b}$ \\ ${ }^{1}$ Atatürk University, Faculty of Veterinary Medicine, Department of Microbiology, Erzurum, Turkey.

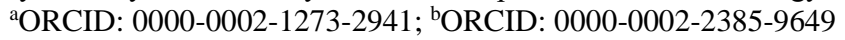 \\ Corresponding author: seydacengiz@atauni.edu.tr \\ Received date: 31.10 .2019 - Accepted date: 02.04.2020
}

\begin{abstract}
Microorganisms have a primary role in the formation of calf diarrhea. Escherichia coli pose an environmental risk to young animals caused by fecal excretion. In this study, rectal swab samples $(n=133)$ were collected from calves with diarrhea aged from 1 day to 3 months, between August 2017 and August 2018. The samples were cultured on MacConkey agar, and then antimicrobial susceptibility and virulence genes for Escherichia coli isolates $(n=133)$ were investigated by disk diffusion method according to clinical and laboratory standards institute standards and multiplex polymerase chain reaction, respectively. The isolates were found to be highly resistant to oxytetracycline (78.9\%), trimethoprim-sulfamethoxazole (69.2\%), neomycin (60.9\%), and erythromycin (58.6\%). Besides, multidrug resistance was determined in $71.4 \%$ of isolates. Thirty-three of $133(24.81 \%)$ isolates were positive for at least one virulence factor. The pathotypes of enterotoxigenic Escherichia coli (F5 and/or F41 fimbria and STa), enterohemorrhagic Escherichia coli (Stx and eae), enteropathogenic Escherichia coli (eae) and Shiga toxin-producing Escherichia coli (Stx-eae) were found in 51.5\%, $6.1 \%, 15.2 \%$, and $12.1 \%$, respectively. However, the virulence properties were detected as; Stx 1 (3.03\%), Stx2 (9.09\%), STa (21.21\%), and eae (15.15\%); the F41 and F5 were not detected. Also, the fifteen-point two percent of strains (5/33) were the hybrid type that carried both Stx (either Stx 1 or Stx2) and enterotoxigenic Escherichia coli specific enterotoxin gene STa. The existence of different virulence factors found in this study supports the statement that calves are possible bearers of pathogens that are dangerous to public health.
\end{abstract}

Keywords: Antimicrobial resistance, diarrhoea, Escherichia coli, hybrid strain, virulence gene.

\section{Türkiye’nin doğusunda buzağı ishallerinden izole edilen E.coli'lerin virulens faktörlerinin ve antimikrobiyel direncinin belirlenmesi}

Özet: Buzağı ishallerinin oluşumunda mikroorganizmalar primer role sahiptir. Escherichia coli, genç hayvanlarda fekal atılıma bağlı olarak çevresel bir risk oluşturmaktadır. Bu çalışmada, Ağustos 2017-Ağustos 2018 tarihleri arasında 1gün ile 3 aylık yaştaki ishalli buzağıların rektal svap örnekleri toplandı $(n=133)$. Toplanan örnekler MacConkey agara ekilerek kültüre edildi ve Klinik Laboratuvar Standartları Enstitüsünün bildirdiği standartlara göre antibiyotik duyarlılıkları belirlendi, multipleks polimeraz zincir reaksiyonu ile de virulens özellikleri incelendi. İzolatlar oksitetrasikline $(\% 78,9)$, trimethoprim-sulfamethoxazole $(\% 69,2)$, neomisine $(\% 60,9)$ ve eritromisine $(\% 58,6)$ yüksek oranda dirençli bulundu. Aynı zamanda, izolatların \%71,4'ünde çoklu direnç saptandı. 133 izolatın 33'ünde $(\% 24,81)$ en az bir virulens faktör pozitif bulundu. Enterotoksijenik E. coli (F5 ve/veya F41 fimbria ve STa), enterohemorajik Escherichia coli (Stx ve eae), enteropatojenik E. coli (eae) ve Shiga toksin oluşturan E. coli (Stx-eae) patotipleri sirasiyla \%51,5, \%6,1, \%15,2 ve \%12,1 oranlarında bulundu. Virulens özellikleri Stx $1 \% 3,03$, Stx2 \%9,09, STa \%21,21 ve eae \%15,15 oranlarında bulunurken, F41 ve F5 bulunamadı. Suşların \%15,2'si hem Stx (Stx1 ve Stx2) hem de enterotoksijenik E. coli'ye spesifik enterotoksin geni STa bulundurduğu için hibrid suş olarak tespit edildi.

$\mathrm{Bu}$ çalışmada farklı virulens faktörlerin varlığının belirlenmesi, buzağıların halk sağlığı açısından tehlikeli olan patojenlerin taşıyıcısı olabileceğini desteklemektedir.

Anahtar sözcükler: Antimikrobiyel direnç, Escherichia coli, hibrit suş, ishal, virulens geni.

\section{Introduction}

Calf diarrhea, which causes serious economic losses, is an important issue in cattle breeding in Turkey and worldwide. Microorganisms, variable environmental conditions, and farming-dependent issues primarily affect the formation of infection $(4,10,13)$. Escherichia coli has environmental epidemiology that causes important risk to young animals. Diarrhea in calves is a common issue in the early years of life and occurs in almost every farm, affecting animal welfare worldwide. Moreover, diarrhea can frequently lead to death in animals in less than one month old. In addition to death, treatment, veterinary costs 
are a crucial issue of economic loss to farmers because of the colibacillosis. Infectious and noninfectious agents play an important role in calf diarrhea. Effective control of calf diarrhea with a multifactorial structure is difficult. Escherichia coli is the most frequently isolated bacteria in calves less than 2 months old. The prevalence of these bacteria in farms depends on the geographical status, farm management, and herd size $(14,19,27)$.

Strains of $E$. coli colonize the host's intestine with different virulence factors and induce diarrhea by escaping the immune system. The virulence factors of bacteria have an important role in colonization and adhesion (F2-F6; F17; F18; F41 fimbria and intimin; LT, STa, and STb; and verotoxin). Virulence factors can be combined, particularly in persistent infections. Escherichia coli pathotypes, such as enterotoxigenic E. coli (ETEC), enteropathogenic E. coli (EPEC), enteroinvasive $E$. coli (EIEC), verotoxin- and Shiga toxin-producing E. coli (STEC), enterohemorrhagic E. coli (EHEC), enteroaggregative E. coli, and enteroadherent $E$. coli (EAEC) strains, may responsible for diarrhea in farm animals and humans. When ETEC infection occurs in young calves, it is called colibacillosis $(19,23,27)$.

Adhesion factors (F17 fimbria, S fimbria, P fimbria, a fimbrial adhesin, and capsule-like adhesin structures) that are involved in the binding of bacteria to cells can be found in the chromosomal structures of E. coli and are encoded by plasmids. Various toxin structures of $E$. coli (Shiga toxin, CNF1, CNF2, labile toxin, and stable toxin) are effective in the pathogenesis of infection with different features. The severity of infection caused by $E$. coli strains with more than one virulence factor may vary depending on the host's immune system $(15,19,24)$. The development of molecular techniques has facilitated the identification of virulence factors; however, it is difficult to determine the virulence factors phenotypically and erroneous results often occur $(15,24)$. Shiga toxinproducing $E$. coli can cause significant acute illnesses, such as severe food-mediated gastrointestinal infections and hemolytic uremic syndrome, and are effective for a long time in humans, causing diarrhea in both animals and humans $(2,9)$.

This study was aimed to reveal the antimicrobial susceptibility and virulence genes of $E$. coli that lead to calf diarrhea in various cattle farms.

\section{Materials and Methods}

Sampling E. coli isolation and identification: Between August 2017 and August 2018, 133 diarrheal calves ( $<3$ months of age) samples were cultured to $E$. coli isolation. The rectal swab samples of calves were collected from Atatürk University Faculty of Veterinary Medicine Animal Hospital that was located in Erzurum, Turkey. It was not known whether the animals were given antimicrobials before sampling. Rectal samples were collected by using sterile swabs containing Stuart medium. The samples were delivered to the laboratory as soon as possible in cold containers and examined bacteriologically without any delay. Samples were directly streaked on the MacConkey agar for the isolation of $E$. coli. The media were incubated at $37^{\circ} \mathrm{C}$ for $24 \mathrm{hrs}$. Lactose positive colonies from each culture were selected and confirmed to be $E$. coli by species-specific PCR after sub-culturing in tryptic soya broth (TSB). All strains were stored in TSB containing $10 \%(\mathrm{v} / \mathrm{v})$ glycerol at $-20^{\circ} \mathrm{C}$ until further use (13).

Detection of virulence factors of $E$. coli strains: $E$. coli strains were sub-cultured on TSB for 16-18 hrs. To extract genomic DNA, the supernatant was discarded after centrifugation of one $\mathrm{ml}$ of the broth culture placed in a $1.5 \mathrm{~mL}$ tube, pellet resuspended in $100 \mu \mathrm{L}$ sterile distilled water, boiled at $100^{\circ} \mathrm{C}$ for $15 \mathrm{~min}$, and centrifuged at $12.000 \times \mathrm{g}$ for $15 \mathrm{~min}$. All of isolates were confirmed as $E$. coli by PCR (29). Then, multiplex PCR (mPCR) was performed to detect the virulence genes (Table 1), (Stx1,

Table 1. Primer sequences, predicted size of PCR products.

\begin{tabular}{|c|c|c|c|}
\hline Primer & Oligonucleotid sequences & Size of product & References \\
\hline $\begin{array}{l}\text { PhoA F } \\
\text { PhoA R }\end{array}$ & $\begin{array}{l}\text { GGTAACGTTTCTACCGCAGAGTTG } \\
\text { CAGGGTTGGTACACTGTCATTACG }\end{array}$ & $468 \mathrm{bp}$ & 29 \\
\hline $\begin{array}{l}\text { Stx } 1 \mathrm{~F} \\
\text { Stx } 1 \mathrm{R}\end{array}$ & $\begin{array}{l}\text { TTC GCT CTG CAA TAG GTA } \\
\text { TTC CCC AGT TCA ATG TAA GAT }\end{array}$ & $555 \mathrm{bp}$ & 15 \\
\hline $\begin{array}{l}\text { Stx } 2 \mathrm{~F} \\
\text { Stx } 2 \mathrm{R}\end{array}$ & $\begin{array}{l}\text { GTG CCT GTT ACT GGG TTT TTC TTC } \\
\text { AGG GGT CGA TAT CTC TGT CC }\end{array}$ & 118 bp & 15 \\
\hline $\begin{array}{l}\text { Intimin F } \\
\text { Intimin R }\end{array}$ & $\begin{array}{l}\text { ATA TCC GTT TTA ATG GCT ATC T } \\
\text { AAT CTT CTG CGT ACT GTG TTC A }\end{array}$ & $425 \mathrm{bp}$ & 15 \\
\hline $\begin{array}{l}\text { F41 F } \\
\text { F41 R }\end{array}$ & $\begin{array}{l}\text { GCA TCA GCG GCA GTA TCT } \\
\text { GTC CCT AGC TCA GTA TTA TCA CCT }\end{array}$ & $380 \mathrm{bp}$ & 15 \\
\hline $\begin{array}{l}\text { K99 F } \\
\text { K99 R }\end{array}$ & $\begin{array}{l}\text { TAT TAT CTT AGG TGG TAT GG } \\
\text { GGT ATC CTT TAG CAG CAG TAT TTC }\end{array}$ & $314 \mathrm{bp}$ & 15 \\
\hline $\begin{array}{l}\text { STa F } \\
\text { STa R }\end{array}$ & $\begin{array}{l}\text { GCT AAT GTT GGC AAT TTT TAT TTC TGT A } \\
\text { AGG ATT ACA ACA AAG TTC ACA GCA GTA A }\end{array}$ & $190 \mathrm{bp}$ & 15 \\
\hline
\end{tabular}


Stx2, STa, F5, F41, and eae) of the isolates $(12,15,24)$. The $50 \mu \mathrm{L}$ of PCR mixture was contained $5 \mu \mathrm{L} 10 \mathrm{X}$ PCR buffer, $1.5 \mathrm{mmol} \mathrm{MgCl}_{2}, 2 \mu \mathrm{L}$ dNTP mix (2.5 mM each of dNTPs), $1 \mu \mathrm{L}$ forward and reverse primers, $0.2 \mu \mathrm{L}$ Taq DNA polymerase $(5 \mathrm{U} / \mu \mathrm{L}$, Thermo Scientific), $5 \mu \mathrm{L}$ templateDNA, and up of molecular grade distilled water. Amplification was performed with 25 cycles of amplification at $95^{\circ} \mathrm{C}$ for $60 \mathrm{sec}$ initial denaturation, $94^{\circ} \mathrm{C}$ for $30 \mathrm{sec}$ of denaturation, $50^{\circ} \mathrm{C}$ for $45 \mathrm{sec}$ of annealing, $70^{\circ} \mathrm{C}$ for $90 \mathrm{sec}$ of extension, and $10 \mathrm{~min}$ of final extension step at $72^{\circ} \mathrm{C}$. The PCR products were subjected to $1 \%$ agarose gel electrophoresis at 130 volts for $30 \mathrm{~min}$ by being stained with ethidium bromide $(0.5 \mu \mathrm{g} / \mathrm{mL})$. E. coli ATCC 25922 DNA was used as the quality control strain for species-specific PCR.

Antimicrobial susceptibility testing: Antimicrobial susceptibilities test for isolates were performed by disk diffusion method according to Clinical and Laboratory Standards Institute (CLSI) guideline (7). The antimicrobial discs (Oxoid, UK) tests were trimethoprimsulfamethoxazole, gentamicin, oxytetracycline, enrofloxacin, chloramphenicol, ofloxacin, ciprofloxacin, marbofloxacin, erythromycin, neomycin, cefoperazone, cefuroxime, ampicillin-sulbactam, and ceftiofur. Escherichia coli ATCC 25922 was used as a control strains. The strains were recorded as susceptible, intermediate, or resistant according to the zone diameter interpretative standards recommended by CLSI. Isolates, which are resistant to three or more antimicrobial classes were defined as multidrug-resistant (MDR) isolate (1).

Statistical analysis: Rates of antimicrobial resistance between carrying virulence genes $E$. coli and non-carrying virulence genes $E$. coli were compared by Pearson's Chi-squared $\left(x^{2}\right)$ tests using the statistical package SPSS version 20. $\mathrm{P}<0.05$ were considered statistically significant for comparisons (9).

\section{Results}

In total, a hundred thirty-three $E$. coli isolated from rectal swabs were confirmed by PCR. Multiplex PCR result showed that $24.81 \%$ (33/133) of E. coli isolates had various virulence genes (Table 2). The virulence genes were detected Stx 1 (3.03\%), Stx2 (9.09\%), STa (21.21\%),

Table 2. Distribution of antimicrobial resistance class pattern for carrying virulence genes of $E$. coli isolates.

\begin{tabular}{|c|c|c|c|}
\hline E. coli patotypes & Virulence gene patterns & $\begin{array}{c}\text { Frequency } \\
(n=33)\end{array}$ & Antimicrobial resistance class patterns* \\
\hline HYBRID & STa -Stx2-F41- INTIMIN & 1 & MCRs, TETs \\
\hline HYBRID & STa-Stx2-F41 & 1 & MCRs, AMGs, PHs, CEPs \\
\hline HYBRID & STa-Stx1-INTIMIN & 1 & MCRs, TETs \\
\hline ETEC & STa-F41-K99 & 2 & MCRs, PHs, TETs \\
\hline ETEC & STa-F41-K99 & 1 & MCRs, TETs \\
\hline ETEC & STa-F41-K99 & 2 & Qs, MCRs, AMGs, PHs, TETs, FPIs \\
\hline ETEC & STa-F41-K99 & 1 & Qs, MCRs, AMGs, PHs, TETs, FPIs, CEPs \\
\hline ETEC & STa-F41-K99 & 1 & Qs, MCRs \\
\hline HYBRID & STa-F41-INTIMIN & 1 & Qs, MCRs, AMGs, PHs, TETs, FPIs, CEPs \\
\hline HYBRID & STa-F41-INTIMIN & 1 & Qs, MCRs, AMGs, PHs, TETs, FPIs \\
\hline ETEC & STa -K99 & 1 & MCRs, AMGs, PHs, TETs \\
\hline ETEC & STa -K99 & 2 & Qs, MCRs, AMGs, TETs, FPIs \\
\hline EHEC & INTIMIN-Stx 1 & 1 & Qs, TETs, FPIs \\
\hline EHEC & INTIMIN-Stx 1 & 1 & Qs, MCRs, AMGs, PHs, TETs, FPIs \\
\hline EPEC & INTIMIN & 2 & Qs, MCRs, AMGs, PHs, TETs, FPIs \\
\hline EPEC & INTIMIN & 1 & MCRs, AMGs, TETs, CEPs, FPIs \\
\hline EPEC & INTIMIN & 1 & Qs, MCRs, AMGs, TETs, CEPs, FPIs \\
\hline EPEC & INTIMIN & 1 & - \\
\hline ETEC & STa & 2 & MCRs \\
\hline ETEC & STa & 2 & Qs, MCRs, AMGs, PHs, TETs, FPIs \\
\hline ETEC & STa & 1 & MCRs, AMGs, TETs, FPIs \\
\hline ETEC & STa & 1 & Qs, TETs, FPIs \\
\hline ETEC & STa & 1 & Qs \\
\hline STEC & Stx 1 & 1 & TETs, FPIs \\
\hline STEC & Stx 2 & 2 & Qs, MCRs, AMGs, PHs, TETs, FPIs \\
\hline STEC & Stx2 & 1 & FPIs \\
\hline
\end{tabular}

*The isolate, which was resistant to one of the antimicrobials in a group, was considered as resistant for that group. Qs: quinolones, MACs: macrolide, AMGs: aminoglycosides, PHs: phenicols, TETs: tetracyclines, CEPs: cephems, FPIs: folate pathway inhibitors. 
and eae $(15.15 \%)$; however, none of them were carried F41 or F5. Escherichia coli with pathotypes ETEC (F5 and/or F41 fimbria and STa), EHEC (Stx and eae), EPEC (eae), and STEC-EHEC (Stx-eae) were found to be $51.5 \%$, $6.1 \%, 15.2 \%$, and $12.1 \%$, respectively. In addition, five of the $33(15.1 \%)$ toxigenic strains, which are harbored 4 strains eae and one strain F41, were hybrid. The isolates showed high rates of resistance to oxytetracycline, trimethoprim-sulfamethoxazole, neomycin, and erythromycin; however, they showed high rates of susceptibility to cefoperazone, ceftiofur, and cefuroxime (Table 3).
The multidrug-resistant $E$. coli strains were determined as $71.4 \%$. Three of five hybrids and two of four STEC strains were MDR. Oxytetracycline resistance was detected at the highest rate of $E$. coli isolates both with and without virulence genes (Table 4). One isolate was susceptible to all antibiotics tested in the study (Figure 1). The relationship between the isolates of carrying and noncarrying virulence genes was statistically non-significant (Table 4).

Table 3. Antimicrobial susceptibility pattern of $E$. coli isolates.

\begin{tabular}{lcccc}
\hline Antibiotics $(\boldsymbol{\mu g})$ & Resistance breakpoint $(\mathbf{m m})$ & $\mathbf{S}(\boldsymbol{\%})$ & I $(\boldsymbol{\%})$ & $\mathbf{R}(\boldsymbol{\%})$ \\
\hline Ampicillin-sulbactam $(20 \mu \mathrm{g})$ & $\leq 11$ & $108(81.2)$ & $10(7.5)$ & $15(11.3)$ \\
Cefoperazone $(75 \mu \mathrm{g})$ & $\leq 15$ & $120(90.2)$ & $2(1.5)$ & $11(8.3)$ \\
Ceftiofur $(30 \mu \mathrm{g})$ & $\leq 19$ & $123(92.5)$ & $0(0.0)$ & $10(7.5)$ \\
Cefuroxime $(30 \mu \mathrm{g})$ & $\leq 14$ & $120(90.2)$ & $1(0.8)$ & $12(9.0)$ \\
Chloramphenicol $(30 \mu \mathrm{g})$ & $\leq 12$ & $56(42.1)$ & $2(1.5)$ & $75(56.4)$ \\
Ciprofloxacin $(5 \mu \mathrm{g})$ & $\leq 15$ & $64(48.1)$ & $3(2.3)$ & $66(49.6)$ \\
Enrofloxacin $(5 \mu \mathrm{g})$ & $\leq 16$ & $61(45.9)$ & $2(1.5)$ & $70(5.6)$ \\
Erythromycin $(5 \mu \mathrm{g})$ & $\leq 13$ & $37(27.8)$ & $18(13.5)$ & $78(58.6)$ \\
Gentamicin $(30 \mu \mathrm{g})$ & $\leq 12$ & $80(60.2)$ & $13(9.8)$ & $40(30.1)$ \\
Marbofloxacin $(5 \mu \mathrm{g})$ & $\leq 14$ & $62(46.6)$ & $5(3.8)$ & $66(49.6)$ \\
Neomycin $(30 \mu \mathrm{g})$ & $\leq 12$ & $42(31.6)$ & $10(7.5)$ & $81(60.9)$ \\
Ofloxacin $(5 \mu \mathrm{g})$ & $\leq 12$ & $55(41.4)$ & $1(0.8)$ & $77(57.9)$ \\
Oxytetracycline $(30 \mu \mathrm{g})$ & $\leq 11$ & $27(20.3)$ & $1(08)$. & $105(78.9)$ \\
Sulfamethoxazole-trimethoprim $(25 \mu \mathrm{g})$ & $\leq 10$ & $40(30.1)$ & $0(0.0)$ & $93(69.9)$ \\
\hline S: Senstive, $\mathrm{I}$ (12)
\end{tabular}

S: Sensitive, I: Intermediate, R: Resistance.

Table 4. Antimicrobial resistance rates between carrying and non-carrying virulence gene $E$. coli isolates*.

\begin{tabular}{lccc}
\hline \multirow{2}{*}{ Antibiotics } & \multicolumn{2}{c}{$\%$ Resistant (number of resistant isolates) } & P \\
& Carrying virulence genes (n= 33) & Non-carrying virulence genes (n= 100) & 0.274 \\
\hline Ampicillin-sulbactam & $6.1 \%(2)$ & $13.0 \%(13)$ & 0.692 \\
Cefoperazone & $9.1 \%(3)$ & $7.0 \%(7)$ & 0.714 \\
Ceftiofur & $6.1 \%(2)$ & $8.0 \%(8)$ & 0.493 \\
Cefuroxime & $6.1 \%(2)$ & $10.0 \%(10)$ & 0.144 \\
Chloramphenicol & $45.5 \%(15)$ & $60.0 \%(60)$ & 0.340 \\
Ciprofloxacin & $42.4 \%(14)$ & $52.0 \%(52)$ & 0.175 \\
Enrofloxacin & $42.4 \%(14)$ & $56.0 \%(56)$ & 0.054 \\
Erythromycin & $75.8 \%(25)$ & $57.0 \%(57)$ & 0.085 \\
Gentamicin & $18.2 \%(6)$ & $34.0 \%(34)$ & 0.175 \\
Marbofloxacin & $39.4 \%(13)$ & $53.0 \%(53)$ & 0.091 \\
Neomycin & $48.5 \%(16)$ & $65.0 \%(65)$ & 0.653 \\
Ofloxacin & $54.5 \%(18)$ & $59.0 \%(59)$ & 0.979 \\
Oxytetracycline & $78.8 \%(26)$ & $79.0 \%(79)$ & 0.363 \\
Trimethoprim-sulfamethoxazole & $63.6 \%(21)$ & $72.0 \%(72)$ & \\
\hline
\end{tabular}

\footnotetext{
*: The statistical package SPSS 20 version was used for the description of antimicrobial patterns.
} 


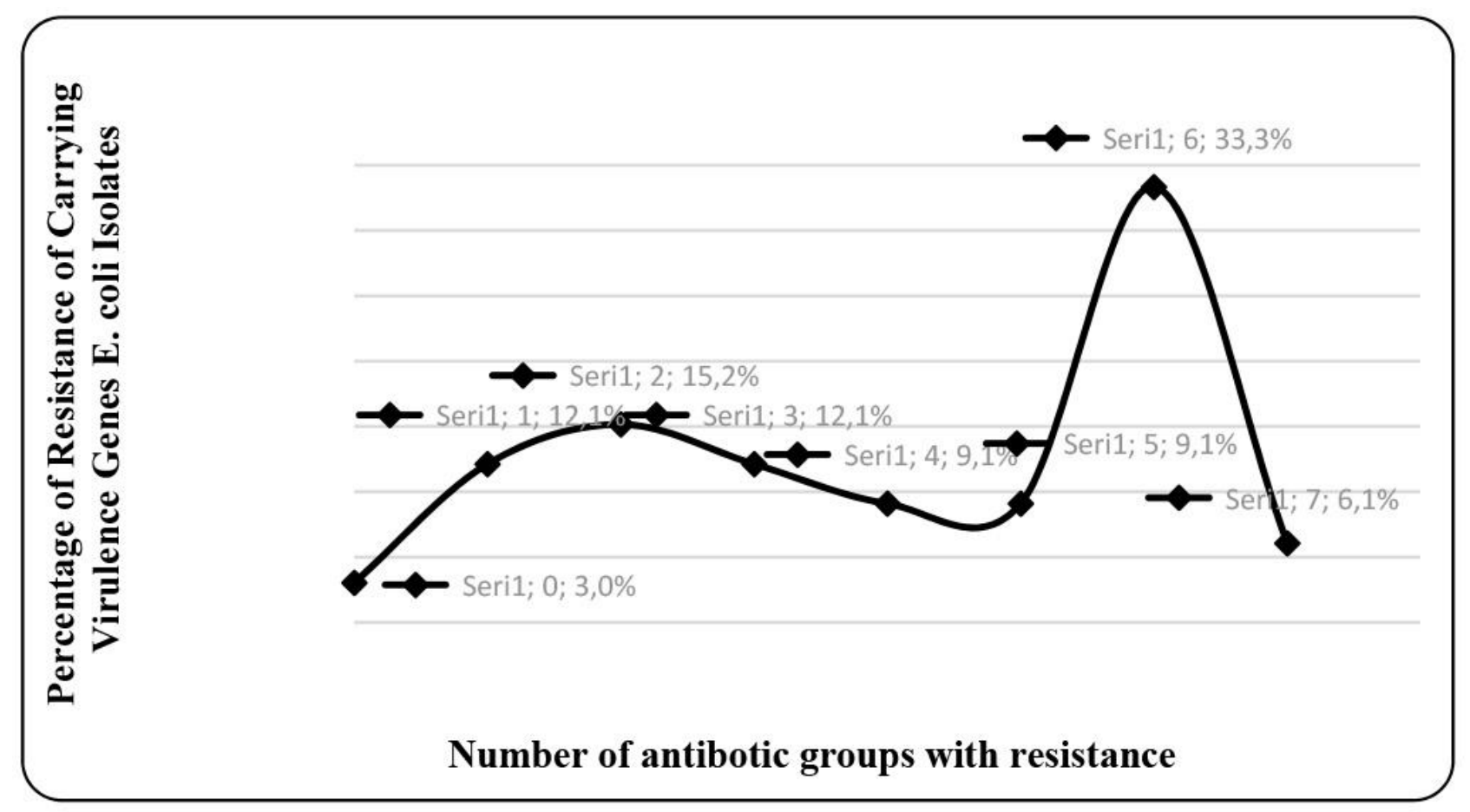

Figure 1. Multidrug resistance rates of carrying virulence gene $E$. coli isolates.

\section{Discussion and Conclusion}

Calf diarrhea is commonly associated with more than one infectious agent, and most outbreaks are caused by multiple factors, including hygiene conditions, nutrition, and the environment. Escherichia coli is the most important bacterial cause of diarrhea in calves. Diarrheagenic E. coli (DEC) is recognized as the major cause of neonatal calf diarrhea with severe lethal outcomes. Virulence factors from several pathogenic $E$. coli strains may predispose calves to diarrhea. Simultaneously, antimicrobial resistance in E. coli strains causes infections that are difficult to treat. Various studies have reported the virulence factors and antimicrobial resistance of such infections in calves $(9,15,24,28)$.

Coura et al. (8) determined that the most common virulence profile of E. coli strains were Stx 2 , Stx 1 , eae, and STa. Hashish et al. (16) reported the most common virulence genes to be STa, Stx1, Stx2, F41, and F5. The F41 virulence gene was determined in 6 and 17 isolates in studies by Andrade et al. (3) and Nguyen, et al. (24), respectively. In previous studies in Turkey, K99 fimbriae were found at a prevalence of $9.4 \%-30.2 \%$ in calves (11, 17, 26, 30). Furthermore, Güler et al. (15) isolated 12 ETEC strains with K99, F41 and STa combinations in Turkey. However, it was determined that the F41 structure with K99 was found only in F41-producing strains and may cause diarrhea. Moreover, the K99 virulence gene was reported to be found in combination with intimin and/or $\operatorname{Stx}(3,24,26)$. In this study was in agreement on
STa and Stx virulence genes with previous studies (3, 16, 24) but different on only F5 and F41 carrying strains with the same studies. These differences were may have been caused by some virulence factors, including phageencoded and plasmid-encoded factors, which are related to the pathogenesis of $E$. coli strains. The presence of fimbrial genes with other virulence genes is considered to increase the virulence of the strains.

Coura et al. (8) reported the pathotypes of E. coli to be $\operatorname{ETEC}(6.8 \%), \operatorname{EHEC}(37.9 \%)$, EPEC (6.8\%), and STEC (48.5\%). Other studies have reported an association between STEC and diarrhea $(16,28)$. E. coli with the pathotypes ETEC, EHEC, EPEC, and STEC-EHEC were found to be $51.5 \%, 6.1 \%, 15.2 \%$, and $12.1 \%$, respectively, in this study. These virulence genes have already been reported to be associated with diarrhea (6). The transfer of virulence-related genes between different virulencebearing E. coli strains results in the development of different pathotypes. These developing pathotypes result in the emergence of the term "hybrid," which was defined as the combination of virulence genes (18). Some researchers have described strains that include the characteristics of EHEC and EPEC pathotypes as hybrid strains $(5,22)$. Nyholm et al. (25) reported $14 \%$ of hybrid strains from animal $E$. coli strains. This ratio is similar to the results of this study $(15.1 \%)$. Hybrid strains have been associated with the hemolytic uremic syndrome, particularly in humans; therefore, the presence of these strains is important not only for animal health but also for 
human health. Although no data exist on the virulence potential of STEC-ETEC hybrid strains isolated from calves and if we consider that patients in this study to our clinic come from different regions of Erzurum, the widespread distribution and clinical relevance might indicate their virulence potential.

In the present study, no virulence factor was detected in 100 E. coli strains isolated from diarrhea samples. This result is in accordance with the results of previous studies $(24,28)$. A possible explanation for this finding is that these strains are nonpathogenic and the diarrhea may cause by another infectious agent like virus and parasite.

Although calf diarrhea associated with E. coli infection is often treated with antimicrobials, treatment may be unsuccessful because of resistant isolates in animals. E. coli isolates acquired from diarrhea were found to be resistant to amoxicillin, tetracycline, and cefotaxime in Bangladesh (4) and to penicillin, streptomycin, tetracycline, lincomycin, and sulfamethoxazole in Iran (28). In Turkey, E. coli isolates were found to be resistant to ampicillin, trimethoprimsulfamethoxazole, kanamycin, tetracycline, nalidixic acid, and enrofloxacin (15). In this study, the isolates were remarkably resistant to oxytetracycline, trimethoprimsulfamethoxazole, and neomycin, with prophylactic and therapeutic usages in calves with diarrhea. Some reports detected MDR strains and it was determined that resistance developed particularly against commonly used antimicrobials such as ampicillin, amoxicillin, clavulanic acid, oxytetracycline, and streptomycin $(1,21,32)$. In this study, MDR strains were found similar to those in other studies $(9,20)$.

The use of antimicrobials in the treatment of bacterial calf diarrhea may be necessary; however, uncontrolled and unconscious use of antimicrobials creates resistance to common antimicrobials and causes MDR in bacteria. It should be noted that $E$. coli strains with MDR may be present in farms that do not use antimicrobials. Walk et al. (31) reported that, irrespective of antimicrobial use, tetracycline resistance is adopted in animals by an undetermined helpful mutation.

In conclusion, we know that the ETEC, EHEC, EPEC and STEC-EHEC strains are really important for calves. On the other hand, STEC-EHEC strains a big concern associated with severe diarrhoea and HUS in human health. Therefore, the defense against these strains is crucial for both animal and human health. Multidrug resistant strains are a global problem. The existence of MDR hybrid type E. coli strains in livestock poses a potential health threat to humans. Consequently, antimicrobial choosing during the infections should base on antimicrobial susceptibility tests. In this study, we provide a data source for an antimicrobial approach to calf diarrhea in our region.

\section{Financial Support}

This study was supported by the Scientific Research Projects Coordination Unit of Atatürk University with the project number of TSA-2017-6091.

\section{Ethical Statement}

This study does not present any ethical concerns.

\section{Conflict of Interest}

The authors declared that there is no conflict of interest.

\section{References}

1. Adiguzel MC, Diren Sigirci B, Celik B, et al (2018): Phenotypic and genotypic examination of antimicrobial resistance in thermophilic Campylobacter species isolated from poultry in Turkey. J Vet Res, 62, 463-468.

2. Al Mawly J, Grinberg A, Prattley D, et al (2015): Risk factors for neonatal calf diarrhoea and enteropathogen shedding in New Zealand dairy farms. The Vet J, 203, 155160.

3. Andrade GI, Coura FM, Santos EL, et al (2012): Identification of virulence factors by multiplex PCR in Escherichia coli isolated from calves in Minas Gerais, Brazil. Trop Anim Health Prod, 44, 1783-1790.

4. Ansari ARMIH, Rahman MM, Islam MZ, et al (2014): Prevalence and antimicrobial resistance profile of Escherichia coli and Salmonella isolated from diarrheic calves. J Animal Health Prod, 2, 12-15.

5. Bielaszewska M, Mellmann A, Zhang W, et al (2011) Characterisation of the Escherichia coli strain associated with an outbreak of haemolytic uraemic syndrome in Germany, 2011: a microbiological study. Lancet Infect Dis, 11, 671-676.

6. Blanchard PC (2012): Diagnostics of dairy and beef cattle diarrhea. Vet Clin North Am Food Anim Pract, 28, 443464.

7. Clinical \& Laboratory Standards Institute (2019): Performance standards for antimicrobial susceptibility testing, $29^{\text {th }}$ edition; M100. CLSI, 29, 320.

8. Coura FM, Freitas MD, Ribeiro J, et al (2015): Longitudinal study of Salmonella spp., diarrheagenic Escherichia coli, Rotavirus, and Coronavirus isolated from healthy and diarrheic calves in a Brazilian dairy herd. Trop Anim Health Prod, 47, 3-11.

9. de Verdier K, Nyman A, Greko C, et al (2012): Antimicrobial resistance and virulence factors in Escherichia coli from Swedish dairy calves. Acta Vet Scand, 54, 2.

10. El-Seedy FR, Abed AH, Yanni HA, et al (2016): Prevalence of Salmonella and E. coli in neonatal diarrheic calves. BJBAS, 5, 45-51.

11. Erganis O, Ates M, Corlu M, et al (1988): Ishalli buzağllarda izole edilen E. coli suşlarında K99 fimbria'nın varlı̆̆ı üzerine bir çalışma. Doğa Vet Hay Derg, 12,158190.

12. Franck SM, Bosworth BT, Moon HW (1998): Multiplex PCR for enterotoxigenic, attaching and effacing, and Shiga 
toxin-producing Escherichia coli strains from calves. J Clin Microbiol, 36, 1795-1797.

13. Gibbons JF, Boland F, Buckley JF, et al (2014): Patterns of antimicrobial resistance in pathogenic Escherichia coli isolates from cases of calf enteritis during the springcalving season. Vet Microbiol, 170, 73-80.

14. Güler L, Gündüz K (2007): Virulence properties of Escherichia coli isolated from clinical bovine mastitis. Turk J Vet Anim Sci, 31, 361-365.

15. Güler L, Gündüz K, Ok Ü (2008): Virulence factors and antimicrobial susceptibility of Escherichia coli isolated from calves in Turkey. Zoonoses Public Health, 55, 249257.

16. Hashish EA, El Damaty HM, Tartor YH, et al (2016): Epidemiological study of diarrheagenic Escherichia coli virulence genes in newborn calves. Pak Vet J, 36, 54-58.

17. Içen H, Arserim NB, Işık N, et al (2013): Prevalence of four enteropathogens with immunochromatographic rapid test in the feces of diarrheic calves in east and southeast of Turkey. Pak Vet J, 33, 496-499.

18. Johura FT, Parveen R, Islam A, et al (2017): Occurrence of hybrid Escherichia coli strains carrying Shiga toxin and heat-stable toxin in livestock of Bangladesh. Front Public Health, 4, 287

19. Kaipainen T, Pohjanvirta T, Shpigel NY, et al (2002): Virulence factors of Escherichia coli isolated from bovine clinical mastitis. Vet Microbiol, 85, 37-46.

20. Lee JH (2009): Antimicrobial resistance of Escherichia coli $O 26$ and 0111 isolates from cattle and their characteristics. Vet Microbiol, 135, 401-405.

21. Manna SK, Brahmane MP, Manna C, et al (2006): Occurrence, virulence characteristics and antimicrobial resistance of Escherichia coli O157 in slaughtered cattle and diarrhoeic calves in West Bengal, India. Lett Appl Microbiol, 43, 405-409.

22. Mellmann A, Harmsen D, Cummings CA, et al (2011): Prospective genomic characterization of the German enterohemorrhagic Escherichia coli O104:H4 outbreak by rapid next generation sequencing technology. Plos One, 6 , e22751.
23. Momtaz H (2010): Investigation of virulence factors in Escherichia coli isolated from clinical and subclinical bovine mastitis. BJVM, 13, 122-126.

24. Nguyen TD, Vo TT, Vu-Khac H (2011): Virulence factors in Escherichia coli isolated from calves with diarrhea in Vietnam. J Vet Sci, 12, 159-164.

25. Nyholm O, Heinikainen S, Pelkonen S, et al (2015): Hybrids of Shigatoxigenic and enterotoxigenic Escherichia coli (STEC/ETEC) among human and animal isolates in Finland. Zoonoses Public Health, 62, 518-524.

26. Ok M, Güler L, Turgut $\mathbf{K}$, et al (2009): The studies on the aetiology of diarrhoea in neonatal calves and determination of virulence gene markers of Escherichia coli strains by multiplex PCR. Zoonoses Public Health, 56, 94-101.

27. Picco NY, Alustiza FE, Bellingeri RV, et al (2015): Molecular screening of pathogenic Escherichia coli strains isolated from dairy neonatal calves in Cordoba province, Argentina. Rev Argent Microbiol, 47, 95-102.

28. Shahrani M, Dehkordi FS, Momtaz H (2014): Characterization of Escherichia coli virulence genes, pathotypes and antibiotic resistance properties in diarrheic calves in Iran. Biol Res, 47, 28.

29. Shome BR, Das Mitra S, Bhuvana M, et al (2011): Multiplex PCR assay for species identification of bovine mastitis pathogens. J Appl Microbiol, 111, 1349-1356.

30. Uysal Y, Erdoğan I, Tavukçuoğlu F, et al (1992): Neonatal buzağ enfeksiyonlarından izole edilen E. coli'lerde K99, F41, F(Y) ve 987 P piluslart ile tsiya stabil enterotoksinin aranması ve serotiplendirme çalışmaları. Pendik Vet Mikrobiyol Derg, 23, 119-132.

31. Walk ST, Mladonicky JM, Middleton JA, et al (2007): Influence of antibiotic selection on genetic composition of Escherichia coli populations from conventional and organic dairy farms. Appl Environ Microbiol, 73, 59825989.

32. Wani SA, Hussain I, Beg SA, et al (2013): Diarrhoeagenic Escherichia coli and salmonellae in calves and lambs in Kashmir: absence, prevalence and antibiogram. Rev Sci Tech 32, 833-840. 